\title{
The Effect of Problem-Based Approach Assisted with Mobile Augmented Reality toward Students' Science Process Skills and Achievement
}

\author{
*Yuliana Wahyu, Kanisius Supardi, Marlinda Mulu, Yosef Firman Narut \\ Primary School Teacher Education Study Program, Universitas Katolik Indonesia Santu \\ Paulus Ruteng, Indoneisa \\ *Corresponding Author e-mail: yulianawahyu76@gmail.com
}

Received: November 2021; Revised: December 2021; Published: December 2021

\begin{abstract}
Problem Based Learning (PBL) is a student-oriented approach. PBL is a student-centered approach that can answer 21t century educational challenges. This research approach applies the PBL approach assisted by Mobile Augmented Reality (MAR) as a technology-based media that combines the virtual world with the real world to science process skills and achievement. The purpose of the study was to investigate the effect of the PBL approach assisted with MAR on the learning process skills and outcomes of the students at the Primary Education Teacher Program of Universitas Katolik Indonesia (UNIKA) St. Paulus Ruteng. The research design used was a pretest/posttest control group design with a one-way MANOVA statistical test. Based on the results of hypothesis testing ( $\mathrm{F}$ test) shows that 1 ) there is a significant difference in the science process skills of students who take learning with the MAR-assisted PBL model and students who take conventional learning; 2) there is a significant difference in the learning outcomes of students who take learning with the PBL model assisted by MAR and students who take conventional learning; 3) there is a significant difference in the skill process and science learning outcomes of students who take learning with the MAR-assisted PBL model and students who take conventional learning.
\end{abstract}

Keywords: Learning Outcomes; PBL; Science process skills; MAR

How to Cite: Wahyu, Y., Supardi, K., Mulu, M., \& Narut, Y. (2021). The Effect of Problem-Based Approach Assisted with Mobile Augmented Reality toward Students' Science Process Skills And Achievement. Prisma Sains : Jurnal Pengkajian Ilmu dan Pembelajaran Matematika dan IPA IKIP Mataram, 9(2), 420-427. doi:https://doi.org/10.33394/j-ps.v9i2.4342

https://doi.org/10.33394/j-ps.v9i2.4342

Copyright@ 2021, Wahyu et al This is an open-access article under the CC-BY License.

\section{INTRODUCTION}

Mastery of science and technology is an important key in facing the challenges of 21 stcentury education and the current era of the industrial revolution 4.0. The Industrial Revolution 4.0 which has raged in various industrial lines cannot be separated from the field of education which must be adaptive, productive, and anticipative in response to developments by preparing graduates who can compete and have a variety of skills (Wahyu, Suastra, Sadia, \& Suarni, 2020). This is inseparable from the development of education in general and science education in particular. Science education is the most important part in preparing students to become qualified human beings so they can compete globally.

Science education is the creation of the human mind with free discovery ideas and concepts (Howe \& Jones, 1993). Scientific theories try to describe reality and determine the relationship between to the facts that exist on earth through scientific discoveries. For this reason, the science education instruction must be meaningful as a provision of knowledge, skills, and attitudes in solving problems in everyday life. Ideally, the goal of teaching science is to achieve all the essence of science all the essence of science, namely science as a product, 
science as a process, and science as a scientific attitude.

However, it should be acknowledged that the results of science education in Indonesia are still far from expectations. So far, it seems that science learning in elementary schools places more emphasis on science as a product rather than science as a process and science as a scientific attitude (Sadia, 2014). The low quality of science education in Indonesia can be seen from the results of the PISA survey for three consecutive years which is always in the lowest order, namely, in 2009 it was ranked 60 out of 65 countries, in 2012 it was ranked 64 out of 65 countries, and in 2015 it was ranked 63 of 72 countries in the world. For the 2015 PISA results, scientific competence has increased significantly, but the achievements are still below the average for the Organization for Economic Cooperation and Development (OECD) countries (PISA, 2006). PISA 2018 for reading and Mathematics and Natural Sciences in Indonesia still hasn't reached the best score. The reading, math, and science scores of the 208 test results were 371, 379, and 396, respectively. These scores decreased compared to the 2015 PISA results (Rahmawati, 2016). The existence of variations in the acquisition of scientific literacy achievement is influenced by three aspects, namely, (1) the role of schools that affect the achievement of science scores, (2) science achievement between students from private schools and public schools shows a significant difference in score achievement, (3) social economy background (kemendikbud, 2016). The achievement of scientific literacy assessment is the most important part of the PISA assessment, so efforts are made to improve good scientific literacy skills and science learning outcomes.

Another indicator of low process skills and science learning outcomes is the factor of unprofessional teaching staff. Lecturers who teach at PGSD have not been able to implement a student-oriented learning process. This can be seen from the data on the odd semester examination results for basic science concepts at PGSD Unika Santu Paulus Ruteng for two consecutive years have not achieved satisfactory results. The 2018/2019 school year was 65.4, the 2019/2020 school year only reached an average of 70.2 (PGSD UNIKA Santu Paulus Ruteng, 2019). The low learning outcomes of science and science process skills are caused by the learning process carried out which is still centered on lecturers, so that learning outcomes only include scientific products, have not reached the essence of science as a scientific process and attitude. Also, there is very little application of a learning process that can measure student process skills. Science process skills are skills that students must possess as a provision in understanding the nature of science as a process. Process skills that must be mastered include basic science process skills and integrated science process skills.

One of the dominant factors thought to affect the low quality of science education is the learning approach applied by the teaching staff. The learning approach implemented in science learning so far tends to use a conventional approach. The science that is taught only reaches the essence of science as a product and ignores the essence of science as a process and science as a scientific attitude. The low science learning outcomes are of course the result of the unsuccessful science learning process being implemented and the curriculum used in the teaching unit. Many factors influence the low learning outcomes of science due to the quality and quantity of teaching staff as learning agents, the quality and quantity of educational infrastructure, and the quality of the teaching and learning process applied in the classroom (Permanasari, 2016). It is necessary to apply learning approach which empowers the students to learn actively, creatively, and innovatively.

Based on the description above, it is assumed that the learning approach that can accommodate all of these is the PBL approach with the help of MAR media. The theoretical foundations underlying the PBL model can be Traced back on the Dewey and Bruner's social constructivism theory (Wahyu \& Davidi, Serba Serbi Pendekatan STEM, 2020). PBL is "... an approach to structuring the curriculum which involves confronting students with problems from practice which provide a stimulus for learning" (Wahyu \& Davidi, Serba Serbi 
Pendekatan STEM, 2020). PBL is a learning model that is accumulated in the KKNI curriculum as a learning model that equips students to have high learning skills. In line with that, PBL is a problem-oriented learning model that is applied to science learning in the classroom. PBL is an approach that focuses on students solving problems through collaborative groups (Hastuti, Hirmampuni , \& Widodo, 2016).

PBL is a learning model based on the principle of using problems as a starting point for the acquisition and integration of new knowledge (Hastuti, Hirmampuni , \& Widodo, 2016). The six stages of the problem-based learning process are: 1) starting with the presentation of the problem; 2) problems related to the real world of students; 3) learning material organization according to the problem; 4) giving students the primary responsibility for shaping and directing their learning; 5) using small groups in the learning process; 6) requiring students to display what they have learned to practice scientific communication skills (Sadia, 2014). PBL learning model is expected to improve student skills in solving learning problems.

The application of the PBL learning model can be supported by the use of instructional media in the technology-based learning process. The application of the PBL learning model can be supported by the use of instructional media in the technology-based learning process, that is Mobile Augmented Reality (MAR). MAR is a form of combining visualization between real and virtual worlds that can increase students' understanding of the real world (Kamphuis, Barsom, Schijven, \& Christoph, 2014).

The purpose of this study was to determine: 1) The differences in science process skills, between students who took the basic concepts of science learning using the MAR-assisted PBL model and students who took conventional learning. 2) Differences in science learning outcomes, between students who take the basic concepts of science learning with the MARassisted PBL model and students who take conventional learning. 3) Differences in science process skills and science learning outcomes, between students who take basic science concepts learning with the MAR-assisted PBL model and students who take conventional learning

\section{METHOD}

\section{Design}

This study used a quasi-experimental research design with a pretest/posttest control group design (Gall, Gall, \& Borg, 2003). Before determining the experimental group and the control group, the equivalence test was carried out using the t-test. Before testing the hypothesis, firstly perform the data normality test, data homogeneity, and data linearity test. Hypothesis testing used Multivariate Analysis of Variants (MANAVA). The research was carried out for 5 months, starting from September 2019 to January 2020 at the Primary Teacher Education Program of UNIKA Santu Paulus Ruteng.

\section{Research Sample}

The population of this study was all students of Primary Teacher Education Program of UNIKA Santu Paulus Ruteng. level II in the academic year 2019/2020 in odd semester. The total population in the study was 150 students in 5 classes. Carrying out research involving all members of the population will cause obstacles in conducting research. Therefore, this study was carried out on several samples in that population.

The selection of class as the research sample used a random sampling technique. By using this random sampling, one experimental class and one control class were selected. Before determining the sample, the equivalence test was carried out on the 5 classes of population members. Class equality is seen from the equality of learning achievement of basic science concepts. The equivalence test was carried out with the t-test at a significant 
level of $5 \%$. After doing the equivalence test, determine the experimental class and the control class.

\section{Instrument}

The instruments used to collect data were process skills observation sheets and multiple choice test to measure student science learning outcomes. Before being used in the research, the instrument was tested and validated by experts. The instrument was tested for reliability and validity. The results of the validity analysis of the instrument resulted in a valid process skills instrument $(0.81>0.30)$ and the learning outcome test items were very valid $(1.0>$ 0.74), because of CVR-hit > CVR-table with CVR-table $=0.74$. Analysis of the construct validity of science question items resulted in invalid data $(0.84>0.30)$.

\section{Data analysis}

The data analysis of this study used one-way analysis of variance (MANOVA) with test F using SPSS 16.0 app.

\section{RESULTS AND DISCUSSION}

\section{Findings}

The process of learning science through the PBL learning model assisted by MAR media uses MAR media from the internet that is downloaded and applied in the science learning process on the concept of organic material in humans, especially the transportation system in humans. The following are the examples of how an image appears in MAR
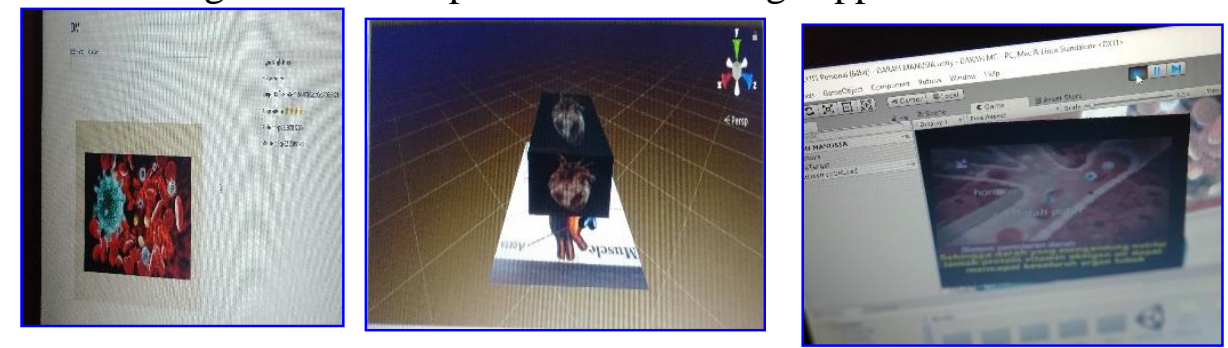

Figure 1. Cross Section of the Material Concept on MAR Developed Through Unity and

\section{Result of Scientific Process Skills}

\section{Vuvoria}

The results of process skills assessed and observed in research are basic and integrated science process skills adopted from (Martin, Mora, Anorbe-Diaz, , \& Antoni, 2005), which consists of observation, classification, communication, measurement, estimation, prediction, inference, identifying variables, controlling variables, experimenting, and investigating. The results of the observation of process skills which consists of 11 indicators are presented in Table 1.

Table 1. Recapitulation Score on the Scientific Process Skills of Students

\begin{tabular}{lll}
\hline Statistics & Experiment & Control \\
\hline Amount of Data (n) & 36 & 36 \\
Average & 121.343 & 113.714 \\
Maximum Score & 136 & 124 \\
Minimum Score & 100 & 96 \\
Mean & 36 & 28 \\
\hline Standard Deviation & 10.186 & 10,40 \\
\hline
\end{tabular}

Table 1 shows that the average score of science process skills of the experimental group students is in the very good category and the average score of the control group students is in 
sufficient category. The diagram of the difference in process skills between students in the experimental and control groups

is shown in Diagram 1.

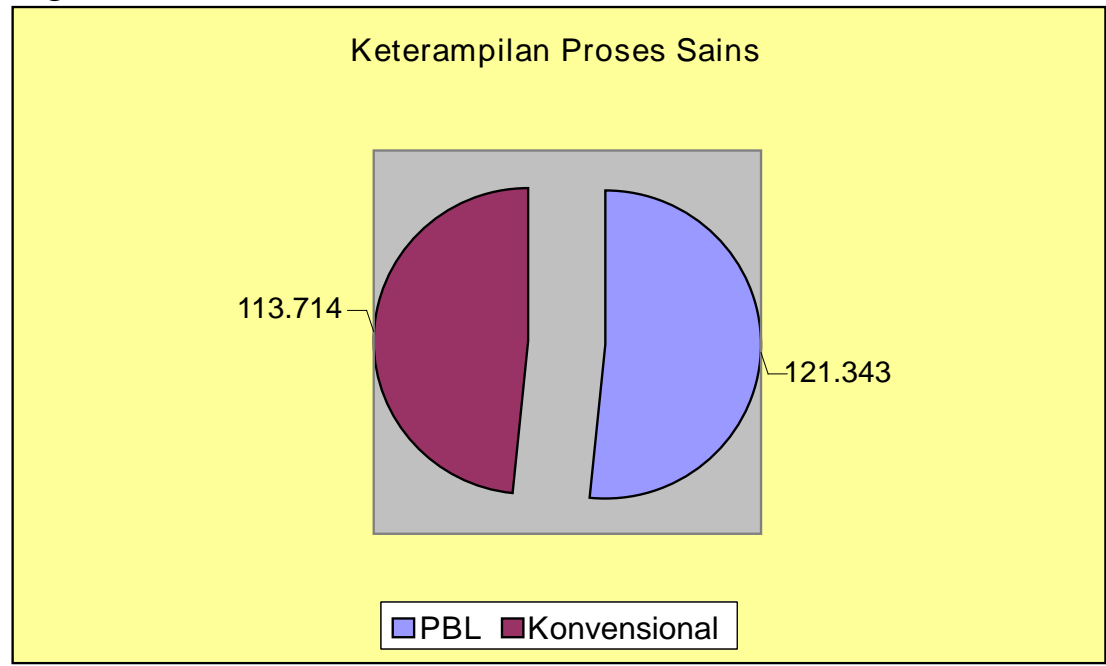

Figure 1. Differences in Science Process Skills of Students in Experiment and Control Groups

\section{Result of Students' Science Achievements}

Table 2 provides information about the students' science learning outcomes after implementing the PBL approach assisted with MAR of the experimental and control groups. Table 2. Recapitulation Score on the Studying Science of Students

\begin{tabular}{lll}
\hline Statistics & Experiment & Control \\
\hline Amount of Data (n) & 36 & 36 \\
Average & 85.6 & 69.4 \\
Maximum Score & 96.7 & 80 \\
Minimum Score & 66.7 & 40 \\
Mean & 30 & 40 \\
\hline Standard Deviation & 41 & 35 \\
\hline
\end{tabular}

Table 2 shows that the average score of science learning outcomes of the students in experimental group is at the very good category, and the students of control group is at the sufficient level. The diagram of the difference in learning outcomes of the two group is shown in Diagram 2.

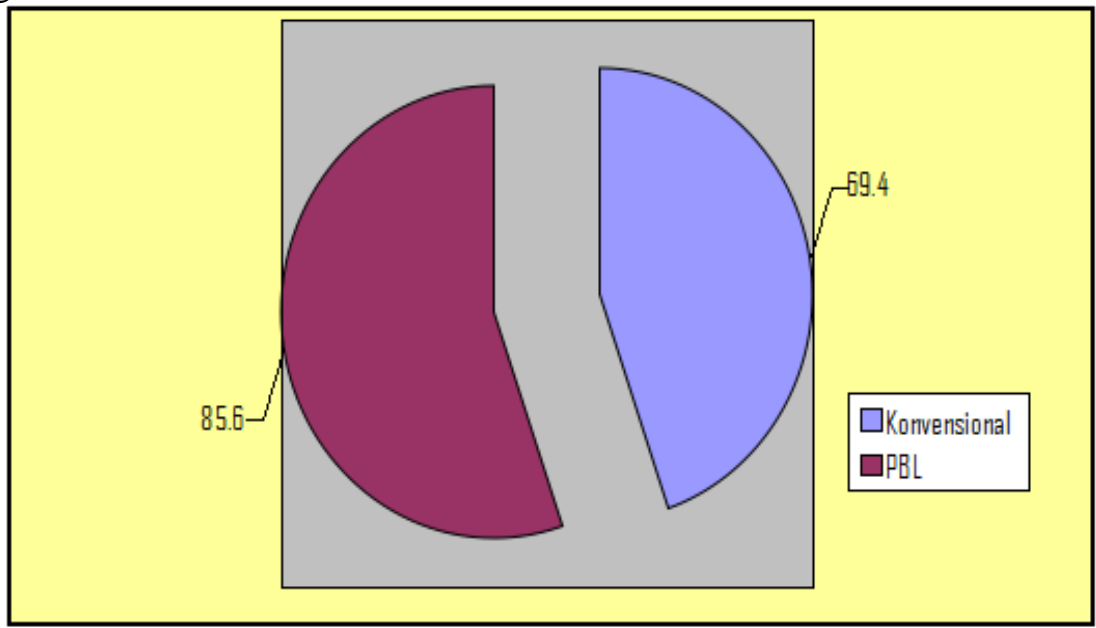

Figure 2. Science Learning Outcomes of Students in The Experimental and Control Groups 


\section{Hypothesis Test}

The results of the test of between-subject's effects on the differences in science process skills of students experimental group and control group, show the value of $F=12.462$ with $p$ $=0.001(<0.05)$ then $\mathrm{H}_{0}$ is rejected. This means that there is a significant difference in science process skills between students who take science learning with MAR-assisted PBL learning model and students who take science learning with conventional learning.

The results of the test on the effectiveness of the application of the MAR-assisted PBL learning model on science process skills showed that the effect size value $=0.5$ with sufficient category. Effect size 50\% shows that the application of MAR-assisted PBL model is quite effective in improving the process skills of students compared to conventional learning.

By using the $\mathrm{F}$ value shows the difference in science learning outcomes between students who take science learning with the MAR-assisted PBL model and students who take conventional learning, $\mathrm{F}$ test $=123.317$ with a significance number of 0.001 and mean $=$ 38.019. The significance number generated from the hypothesis test is below the specified level of significance, thus $\mathrm{HO}$ is rejected. It can be concluded that, there are significant differences in science learning outcomes between students who take science learning with the MAR-assisted PBL model and students who take conventional learning. Because there are differences in learning outcomes of basic science concepts that differ significantly between the two groups, it is necessary to carry out further tests. Follow-up tests performed with LSD, Scuffed, Tukey's-b and Dun net yielded a significant value of less than 0.05. Since the confidence level $\alpha=0.05$, all further tests for all pairs of the sample groups are significant.

The results of the multivariate test analysis showed that F-Pillai's Trace, Wilks' Lambda, Hoteling's Trace, and Roy's Largest Root $=66.747$ with $p=0.001(<0.05)$ then H0 is rejected, i.e. there is a difference in science process skills and science learning outcomes between participant's students who follow science learning with MAR-assisted PBL model learning with students who take science learning with conventional learning. This means that there are significant differences in science process skills and science learning outcomes between students who take science learning with MAR-assisted PBL model learning and students who take science learning with conventional learning.

\section{Discussion}

The results of hypothesis testing about the differences in science process skills between students who took the MAR-assisted PBL model of science learning and students who took conventional learning showed that $\mathrm{H} 0$ was rejected, meaning that by applying the MARassisted PBL model, the student's process skills increased. This means that there is a significant difference in science process skills between students who take the MAR-assisted PBL model of science learning and students who take conventional learning. The results of this study support the results of research conducted by (Suryaningsih, 2018) which shows that science process skills are very important to be developed in science learning balanced with the application of an appropriate learning model. The results of this study are also in line with the results of research conducted by (Nugraha, Suyitno, \& Susilaningsih, 2017) which showed that the application of the PBL model can develop children's reasoning abilities in learning. PBL which is oriented towards problem-solving can train students to solve learning problems.

The results of this study are in line with the results of research conducted by Herzon and colleagues (Herzon, B, \& Utomo, 2018) regarding the application of PBL to critical thinking skills. The results of the research show that the application of PBL can develop critical thinking skills in students. The results of this study also reinforce the results of research conducted by (Pratama, 2018) which showed that the application of PBL can improve metacognitive skills in students. 
The results of testing the third hypothesis through a multivariate test on differences in science process skills and science learning outcomes between students who take the MARassisted PBL model of science learning and students who take conventional learning show that this significant number is below the specified level of significance, thus $\mathrm{H}_{0}$ is rejected. This means that there are significant differences in science process skills and science learning outcomes simultaneously between students who take the MAR-assisted PBL model of science learning and students who take conventional learning. The results of this study prove that learning science with the MAR-assisted PBL model has a positive effect on science process skills and student science learning outcomes.

\section{CONCLUSION}

Based on the results of hypothesis testing and the discussion that has been described, it can be concluded that the PBL model of science learning assisted by MAR in science learning has a positive effect on science process skills and student science learning outcomes. In more detail, it can be concluded as follows. There is a significant difference in science process skills between students who take the MAR-assisted PBL science learning model and students who take conventional learning. There is a significant difference in science learning outcomes between students who take the MAR-assisted PBL model of science learning and students who take conventional learning. There is a significant difference in science process skills and science learning outcomes simultaneously between students who take the MARassisted PBL model of science learning and students who take conventional learning.

\section{RECOMMENDATION}

Learning by applying the MAR-assisted PBL model needs to be developed and applied in science learning at PGSD in accordance with the demands of the KKNI curriculum. Further research can be carried out on other material concepts with a wider sample. Student factors that need further research are student interest, motivation, intelligence, self-concept, cognitive style and learning achievement. The MAR-assisted PBL model can be applied to basic education, vocational education, education, secondary, and higher education.

\section{REFERENCES}

Gall, D. M., Gall, J. P., \& Borg, W. R. (2003). Educational Research, Seventh Edition. USA: Pearson Education, Inc.

Hastuti, W. P., Hirmampuni , A. P., \& Widodo, P. (2016). Development Of Inquiry Science Issues-Based Student Worksheet To Advance Practical Skill And Environmental Attitude In a Seventh Grade High School Students". Yogykarta State Univer. Journal Science Education, 1-8.

Herzon, H. H., B, B., \& Utomo, H. D. (2018). Herzon, H.H., Budijanto, \& Utomo, D. H., "Pengaruh Problem-Based Learning (PBL) terhadap Keterampilan Berpikir Kritis. Jurnal Pendidikan Geografi-Pascasarjana Universitas Negeri Malang, 1-10.

Howe, C. A., \& Jones, L. (1993). Engaging Children In Science. New York: Macmillan Publishing Company.

Kamphuis, C., Barsom, E., Schijven, M., \& Christoph, N. (2014). Augmented reality in medical education? Perspect Med Educ, 300-311.

kemendikbud. (2016). Peringkat dan Capaian PISA mengalami Peningkatan. Jakarta: Biro Komunikasi dan Layanan Masyarakat Kementrian Pendidikan dan Kebudayaan.

Martin, R., Mora , C. E., Anorbe-Diaz, , B., \& Antoni. (2005). Teaching Science for All Children Inquiry Methods for Constructing Understanding. Boston: Boston: Pearson education inc. 
Nugraha, A. J., Suyitno, H., \& Susilaningsih, E. (2017). Analisis Kemampuan Berpiki Kritis Ditinjau dari Keterampilan Proses Sains dan Motivasi Belajar melalui Model PBL. Journal of Primary Education, Prodi Pendidikan Dasar, Pascasarjana, Universitas Negeri Semarang, 35-43.

Permanasari, A. (2016). STEM Education: Inovasi dalam Pembelajaran Sains", Aurakarta, 22 Oktober 2016, h. 23-34. Prosiding Seminar Nasional Pendidikan Sains (SNPS) (pp. 23-34). Surakarta: SNPS.

PGSD UNIKA Santu Paulus Ruteng. (2019). Rata-rata KHS Mahasiswa PGSD Unika Santu Paulus Ruteng. Ruteng: PGSD UNIKA Santu Paulus Ruteng.

PISA. (2006). Result From PISA 2000 For Indonesia. Country Note: OECD.

Pratama, A. T. (2018). mproving Metacognitive Skill Using Problem Based Learning (PBL) at Natural Science of Primary School in Deli Serdang, Indonesia. Journal Biology Education, Faculty of Teacher Training and Education, Universitas Muslim Nusantara, 100-105.

Rahmawati. (2016). Hasil TIMSS 2015. Purwarkarta: Seminar Nasional Purwarkarta.

Sadia, I. W. (2014). Model-model Pembelajaran Sains Konstruktivistik. Yogyakarta: Graha Ilmu.

Suryaningsih, Y. (2018). Pembelajaran Berbasis Praktikum Sebagai Sarana Siswa untuk Berlatih Menerapkan Keterampilan Proses SAins dalam Materi Biologi”. 2018. Jurnal Bio Education Program Studi Pendidikan Biologi Universitas Majalengka , Volume 2, Nomor 2, 1-12.

Wahyu, Y., \& Davidi, E. I. (2020). Serba Serbi Pendekatan STEM. Ruteng: UNIKA Santu Paulus Ruteng.

Wahyu, Y., Suastra, I. W., Sadia, I. W., \& Suarni, K. N. (2020). The Effectiveness of Mobile Augmented Reality Assisted STEM-Based. International Journal of Instruction, 343356. 